\title{
Teaching NeuroImages: Dyke-Davidoff-Masson syndrome
}

Robert Durcan, MBBCh, BAO, MRCPI, Shane Smyth, MD, and Ferdia Bolster, MD

Neurology ${ }^{\circledR}$ 2018;90:e2097-e2098. doi:10.1212/WNL.0000000000005640

Figure 1 Coronal and axial MRI
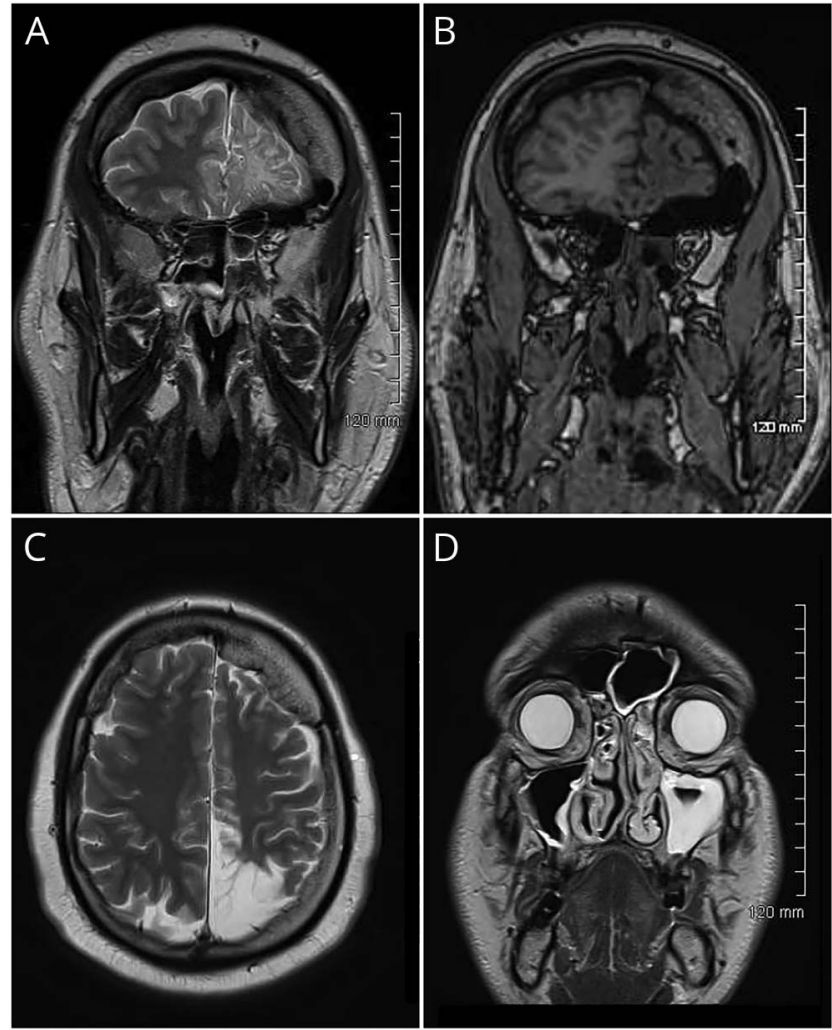

Coronal and axial MRI (A-C) demonstrate asymmetric left-sided cerebral hemiatrophy and encephalomalacia with associated overlying compensatory left calvarial thickening. There is also enlargement of the left frontal sinus on coronal MRI (D).

A 50-year-old man with epilepsy from age 6 presented with seizures and personality change. Neuroimaging demonstrated left cerebral hemiatrophy, calvarial thickening, and increased frontal sinus pneumatization. There was a small, left frontal lobe hemorrhage (not shown), presumably from unwitnessed trauma. The appearances (figure 1) were compatible with DykeDavidoff Masson (DDM) syndrome. ${ }^{1} \mathrm{He}$ remains seizure-free on an increased dose of sodium valproate. His personality changes persist.

DDM results from an in utero or childhood cerebral insult resulting in cerebral atrophy with calvarial and sinus remodelling. ${ }^{2}$ There was a subtle sign of limb asymmetry, unnoticed by the patient or family (figure 2).

\author{
Correspondence \\ Dr. Durcan \\ robertdurcan@rcsi.ie
}

\section{MORE ONLINE}

$\rightarrow$ Teaching slides

links.lww.com/WNL/

A508 
Figure 2 Size discrepancy between distal thumbs, possibly from early childhood neurologic insult

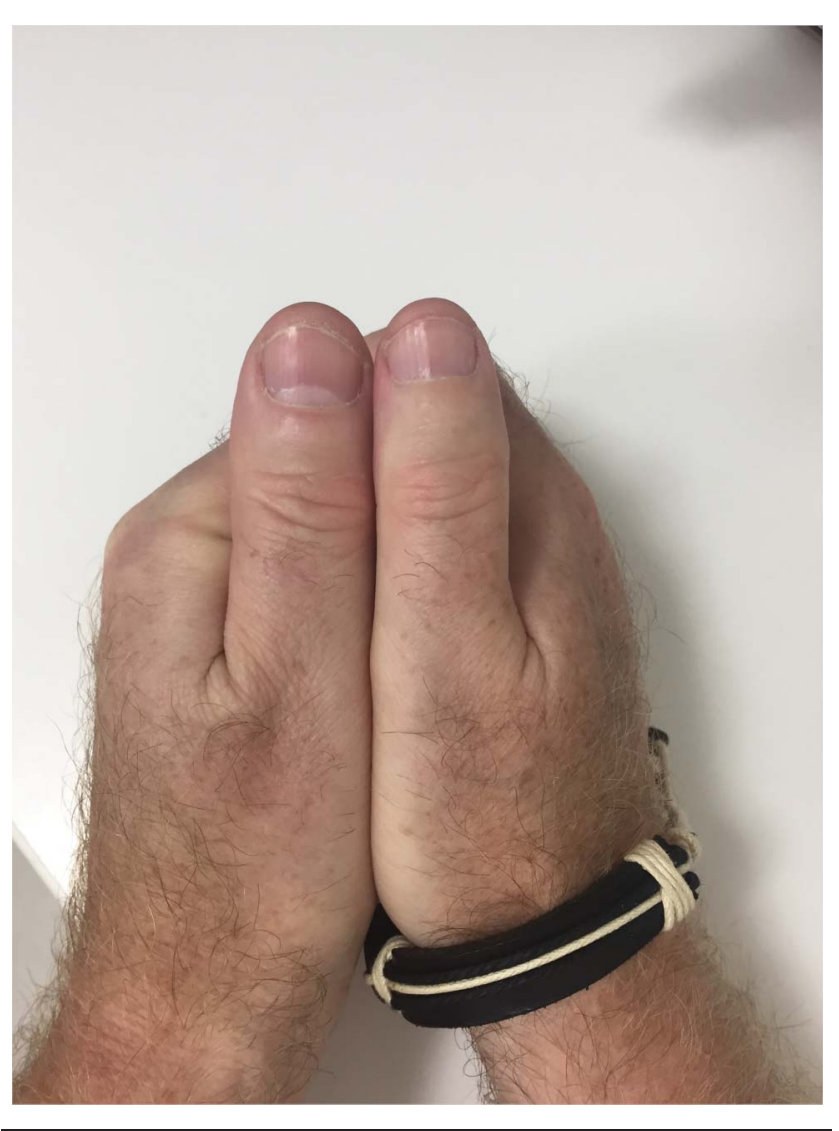

\section{Author contributions}

Robert Durcan: writing of case, literature review, formatting of document. Shane Smyth: critical analysis of case and description, provision of clinical photograph. Ferdia Bolster: critical analysis of radiologic findings.

\section{Study funding}

No targeted funding reported.

\section{Disclosure}

The authors report no disclosures relevant to the manuscript. Go to Neurology.org/N for full disclosures.

\section{References}

1. Dyke CG, Davidoff LM, Masson CB. Cerebral hemiatrophy and homolateral hypertrophy of the skull and sinuses. Surg Gynecol Obstet 1933;57:588-600.

2. Chand G, Goel R, Kapur R. Dyke-Davidoff-Masson syndrome. Arch Neurol 2010;67: 1026. 


\section{Neurology}

\section{Teaching NeuroImages: Dyke-Davidoff-Masson syndrome \\ Robert Durcan, Shane Smyth and Ferdia Bolster \\ Neurology 2018;90;e2097-e2098 \\ DOI 10.1212/WNL.0000000000005640}

\section{This information is current as of June 4, 2018}

\section{Updated Information \& Services}

\section{References}

Subspecialty Collections

Permissions \& Licensing

Reprints including high resolution figures, can be found at: http://n.neurology.org/content/90/23/e2097.full

This article cites 2 articles, 0 of which you can access for free at: http://n.neurology.org/content/90/23/e2097.full\#ref-list-1

This article, along with others on similar topics, appears in the following collection(s):

All Epilepsy/Seizures

http://n.neurology.org/cgi/collection/all_epilepsy_seizures Brain trauma

http://n.neurology.org/cgi/collection/brain_trauma

Developmental disorders

http://n.neurology.org/cgi/collection/developmental_disorders

MRI

http://n.neurology.org/cgi/collection/mri

Information about reproducing this article in parts (figures,tables) or in its entirety can be found online at:

http://www.neurology.org/about/about_the_journal\#permissions

Information about ordering reprints can be found online:

http://n.neurology.org/subscribers/advertise

Neurology ${ }^{\circledR}$ is the official journal of the American Academy of Neurology. Published continuously since 1951, it is now a weekly with 48 issues per year. Copyright @ 2018 American Academy of Neurology. All rights reserved. Print ISSN: 0028-3878. Online ISSN: 1526-632X.

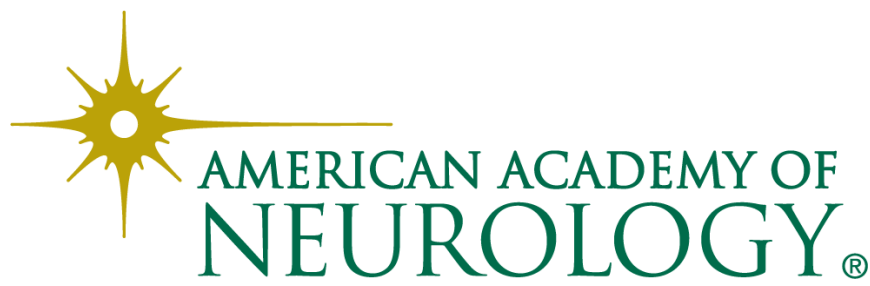

